\title{
Drying rate and quality attributes of foam-mat dried tomato pulp
}

\section{Joshua Olanrewaju Olaoye, Obafemi Ibitayo Obajemihi}

\author{
Department of Food Engineering, Faculty of Engineering and Technology, \\ University of Ilorin, Ilorin, Nigeria
}

\begin{tabular}{|c|c|}
\hline & Abstract \\
\hline $\begin{array}{l}\text { Keywords: } \\
\text { Tomato } \\
\text { Pulp } \\
\text { Drying } \\
\text { Rate } \\
\text { Foam }\end{array}$ & $\begin{array}{l}\text { Introduction. Tomato is a short duration fruit that } \\
\text { deteriorates easily after harvest, hence the need to process it } \\
\text { using foam-mat drying as a technique, to produce tomato with } \\
\text { good quality and investigate some process parameters (foaming } \\
\text { agent and foam stabilizer concentration) that can influence } \\
\text { drying rate and quality of the dried powder. }\end{array}$ \\
\hline Article history: & $\begin{array}{l}\text { egg white as foaming agent at } 3 \text { levels of concentration } 5 \% \text {, } \\
10 \% \text { and } 15 \% \text { and carboxyl methyl cellulose (CMC) at } 0.2 \% \text {, }\end{array}$ \\
\hline $\begin{array}{l}\text { Received } \\
16.04 .2017 \\
\text { Received in revised } \\
\text { form } 29.05 .2017 \\
\text { Accepted } \\
\text { 23.06.2017 }\end{array}$ & $\begin{array}{l}0.4 \% \text { and } 0.8 \% \text { the whipping time at } 3 \text { minutes and the samples } \\
\text { were dried in a cabinet dryer at } 70{ }^{\circ} \mathrm{C} \text {. } \\
\text { Results and Discussion. The result show that the mean for } \\
\text { samples treated with foaming agent concentration at } 5 \%, 10 \% \\
\text { and } 15 \% \text { had drying rates of } 19.21 \mathrm{~g} / \mathrm{hr}, 21.53 \mathrm{~g} / \mathrm{hr} \text { and } 20.46 \\
\mathrm{~g} / \mathrm{hr} \text {, protein content of } 24.66 \%, 24.72 \% \text { and } 24.77 \% \text { and } \\
\text { vitamin C content of } 1.70 \%, 1.44 \% \text { and } 1.34 \% \text { respectively }\end{array}$ \\
\hline $\begin{array}{l}\text { Corresponding } \\
\text { author: }\end{array}$ & $\begin{array}{l}0.8 \% \text { had drying rates of } 18.74 \mathrm{~g} / \mathrm{hr}, 20.68 \mathrm{~g} / \mathrm{hr} \text { and } 21.78 \mathrm{~g} / \mathrm{hr} \text {, } \\
\text { protein content of } 24.71 \%, 24.71 \% \text { and } 24.74 \% \text { and vitamin } \mathrm{C} \\
\text { content of } 1.43 \%, 1.56 \% \text { and } 1.49 \% \text { respectively. Analysis of }\end{array}$ \\
\hline $\begin{array}{l}\text { Olaoye Joshua } \\
\text { Olanrewaju } \\
\text { E-mail: } \\
\text { jolanoye@ } \\
\text { unilorin.edu.ng }\end{array}$ & $\begin{array}{l}\text { Variance shows that foaming agent and foam stabilizer } \\
\text { concentration had no significant effect on drying rate at } \mathrm{P} \leq 0.05 \text {, } \\
\text { but foaming agent had significant effect on protein and vitamin } \\
\mathrm{C} \text { contents of the sample. Analysis of Variance also shows that } \\
\text { the interaction that exist between foaming agent and foam } \\
\text { stabilizer had significant effect on the vitamin } \mathrm{C} \text { and protein }\end{array}$ \\
\hline & $\begin{array}{l}\text { content of the sample but had no significant effect on the } \\
\text { drying rate at } \mathrm{P} \leq 0.05 \text {. Furthermore the New Duncan Multiple } \\
\text { Range Test (NDMRT) shows the means of protein content } \\
24.66 \%, 24.72 \% \text { and } 24.77 \% \text { at foaming agent concentration of } \\
5 \%, 10 \% \text { and } 15 \% \text { respectively. } \\
\text { Conclusions. Foaming agent concentration is an important } \\
\text { parameter that influences the quality attributes of foam-mat } \\
\text { dried tomato. In order to achieve maximum retention of the } \\
\text { vitamin C content of foam-mat dried tomato pulp, } 5 \% \\
\text { concentration of the foaming agent (egg albumin) is more ideal } \\
\text { compared with higher concentrations as this will go a long way }\end{array}$ \\
\hline $\begin{array}{l}\text { DOI: } \\
\text { 10.24263/2304- } \\
974 X-2017-6-2-14\end{array}$ & $\begin{array}{l}\text { to minimize overall cost incurred during foam-mat drying } \\
\text { process. }\end{array}$ \\
\hline
\end{tabular}




\section{Introduction}

Tomato (Lycopersicon esculentum) is a fruit of high economic value and importance. It is widely consumed in Sub-Saharan Africa, Nigeria inclusive [1] and other parts of the world $[2,3]$. It is a fruit consumed on daily basis by people due to its enriching nutritional values, tomato has been known to be a supplier of important nutrients to the human body as one medium sized is capable of supplying the body with $57 \%, 35 \%$ and $8 \%$ of the Recommended Daily Allotment (RDA) of vitamin C, vitamin A and iron, respectively [4]. Tomato fruit has been known for its potency to help boost body immune system and as well prevent against some common and deadly diseases such as prostate, lung and stomach cancer $[5,6]$. As good as tomato fruit is in Nigeria; it is relatively scarce during its off season and as result quite expensive following its season of abundance in large quantities and substantially wasted due to inadequate postharvest handling, processing and storage techniques. One major problem is that tomato is a short duration fruit which easily deteriorates after harvest leading to heavy postharvest losses [7]. As a result it is important to process the fruit, which will minimize wastages incurred and as well make the fruit readily available throughout the year for consumption. Drying has been known to be an economical food processing technique and is gaining popularity in Nigeria [7]. Drying has numerous methods which include Foam-mat drying, spray drying, vacuum drying, solar drying, hot-air drying, freeze drying, microwave drying, infra-red drying, drum drying, fluidized bed drying and osmotic drying etc.

Among these, foam-mat drying is considered to be advantageous in terms of drying of the foams at lower temperature compared with other methods of drying non-foamed materials in the same dryer type [8]. Also the residence time of the product in the dryer is shorter, since there is increased surface area by incorporation of air/gas which increases exposure to heat and aids mass transfer during drying. Drying by foam is a process in which liquid is beaten by various means to form stable foam that is then dried by evaporation of the water in form of thin layer [9]. According to [10], foams-mat process involves drying thin layers of foamed material in heated un-dehumidified air at atmospheric pressure and is reported to be considerably cheaper than vacuum, freeze and spray drying methods. The structure, expansion and stability of the foam provide an important function in the movement of the moisture during drying and, consequently, in the food quality $[11,12]$. Foam drying allows for the processing of biomaterials that are difficult to dry, such as tomato paste and also allows for the production of materials that can easily rehydrate and retain several quality indicators, such as colour, aroma, texture and nutritional values. It is in view of this, this study was carried out purposely to investigate the effects of foaming agent and foam stabilizer on protein and vitamin $\mathrm{C}$ contents of powdered tomato.

\section{Materials and Methods}

\section{Materials}

The experiment was conducted in the department of food engineering, university of Ilorin, Ilorin, Nigeria at average room temperature of $31{ }^{\circ} \mathrm{C}$ and relative humidity of about $60 \%$. Roma tomato fruits that were considered to be fresh, firm, and ripe were purchased from Oja-Oba market in Ilorin, Kwara State, Nigeria. The tomato fruits were sorted according to size and shape in order to ensure uniformity of the samples. Thereafter the samples were washed under running water and sanitized. The samples were blanched with 
steam for 20 seconds to deactivate any enzyme activity and as well hinder the growth of microbes. The samples were deseeded sliced in quarters and were blended with an electric jug blender (Model no. SB-211, 350 W) to form tomato paste. The tomato paste was poured to fill the square containers made with stainless steel of $0.000144 \mathrm{~m}^{3}$ volume.

\section{Methods}

All the containers were foamed with egg whites at different concentrations of 5\%,10\% and $15 \%$ and carboxyl methyl cellulose (CMC) was used to stabilize the foam at different concentrations of $0.2 \%, 0.4 \%$, and $0.8 \%$ according to the experimental treatment layout. The mixtures were agitated with the blender (which was opened at the top to admit in air) to produce foams at constant whipping time of 3 minutes. The experiment was conducted in a $3^{2}$ factorial experiment in Randomized Complete Block Design (RCBD) with each of the treatments replicated thrice to ensure reliability of the experiments' result. Therefore the nine (9) treatments resulted in a total of 27 samples altogether. The containers with the samples labelled appropriately with tags based on their treatments and were loaded onto a mechanical dryer designed and constructed for this experiment (see the exploded view of the dryer in Figure 1). The dryer was run for 10 minutes at $70{ }^{\circ} \mathrm{C}$ and the temperature was monitored in the dryer with the aid of thermometers to ensure it has reached the desired temperature before the samples were loaded onto it. This temperature was chosen because it was considered to be the best for foam mat drying of tomatoes [13, 14]. During the process of drying the samples were being weighed with a weighing scale (CL 201) on hourly basis to determine their moisture loss and were recorded, drying process was terminated when the samples have reached a moisture content of $4.5 \%(\mathrm{db})$ and this took an average drying time of four (4) hours. Scrapers are used to scrape the dried tomato samples out of the containers and allowed to cool and then packaged in polythene with tags and were immediately taken to the laboratory for proximate analysis.

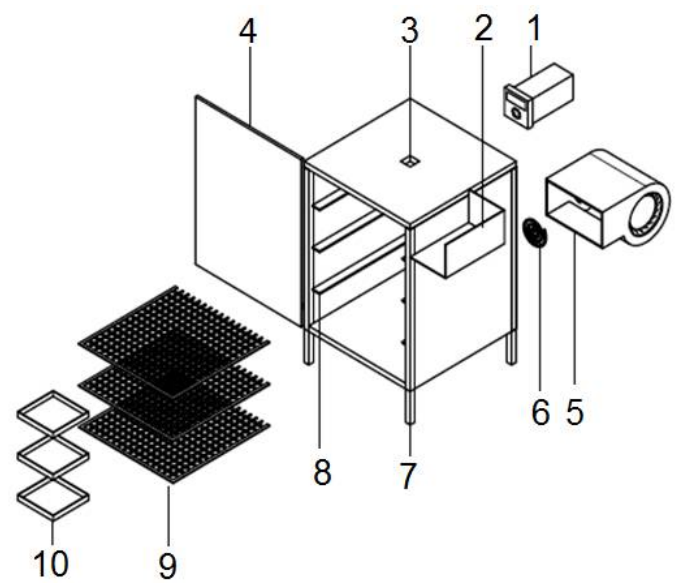

Figure 1. Exploded view of the mechanical dryer:

1 - Heat Regulator; 2 - Heat Regulator Frame ;3 - Chimney; 4 - Door;

5 - Blower; 6 - Heating Element; 7 - Frame/Stand; 8 - Tray Holder; 9 - Main Tray; 10 - Loading Tray; 11 - Dryer Tray/Net 


\section{- Food Technology —}

The Drying rates of the samples were calculated based on the formula from [15]

where: $R$ - Drying rate $(\mathrm{g} / \mathrm{hr})$

$$
R=\frac{d m}{d t}=\frac{m_{i}-m_{f}}{t}
$$

$d M$ - Change in mass $(\mathrm{g})$

$d t$ - Change in time (hr)

$t$ - Total time (hr)

$m_{\mathrm{i}}-$ Initial mass of the sample $(\mathrm{g})$

$m_{\mathrm{f}}-$ Final mass of the sample $(\mathrm{g})$

Proximate composition analysis was carried out at the Chemistry department laboratory to determine the vitamin $\mathrm{C}$ and protein contents of the dried samples using AOAC method [16].

Statistical analysis was carried out using a software SPSS version 16.0 to analyse the data at the level of significance of individual treatments and their interaction with one another at $(\mathrm{p} \leq 0.05)$ using analysis of variance (ANOVA).

\section{Results and Discussion}

\section{Effects of foaming agents and foam stabilizers on the drying rate}

Analysis of variance (ANOVA) table is presented in Table 1 to show the effect of foaming agent and foam stabilizer on the drying rate of foam-mat dried tomato powder as it can be seen in the table both foaming agent and foam stabilizer had no significant effects on the drying rate of the dried samples at $\mathrm{P} \leq 0.05$ this result is similar to the findings of [17] that foaming agent concentration had no significant effect on the foam density of tomato pulp; and [18] and [12] had earlier stated that lower density of foamed materials are responsible for increased drying rate as a result of increased contact surface and interfacial area. That foam stabilizer had no significant effect on the drying rate of foam-mat dried tomato powder.

Table 2 was used to show the effects of various concentration of foaming agent (egg white) on the rate at which the samples dried using the new Duncan's multiple range test (NDMRT), from the table the use of foaming agent at 5\%,10\% and $15 \%$ show mean drying rates of $19.21,21.53$ and $20.46 \mathrm{~g} / \mathrm{hr}$ respectively which show that the fastest rate of drying was achieved with samples treated with $10 \%$ foaming agent and the slowest with those treated with $5 \%$ foaming agent but Table 2 also show that at significant level of $\mathrm{P} \leq 0.05$ the use of foaming agent at various concentration had no significant differences from each other. This implies that varying foaming agent concentration may not be necessary when trying to get optimum drying rate.

Table 3 show the effect of foam stabilizer, carboxyl methyl cellulose (CMC) at different concentrations on the drying rate. Samples treated with $0.20 \%, 0.40 \%$ and $0.80 \%$ of CMC had mean drying rates of $18.74,20.68$ and $21.78 \mathrm{~g} / \mathrm{hr}$ respectively. These show that the fastest drying rate was achieved at $0.80 \%$ CMC concentration, however the new Duncan's multiple range test (NDMRT) in Table 3 has been used to compare the mean of drying rate at different concentrations of $\mathrm{CMC}$ which reveals that they were not significantly different from each other statically at $\mathrm{P} \leq 0.05$. Therefore energy, time and 
resources should not be wasted varying foam stabilizer concentration when the aim of the drying experiment is to enhance drying rate. As it shown in Table 4 the interactive effect of foaming agent and foam stabilizer on drying rate is not significant at $\mathrm{P} \leq 0.05$.

Table 1

Results of the analysis of variance (ANOVA) of effect of foaming agent and foam stabilizer on drying rate, vitamin $C$ and protein content of foam-mat dried tomato pulp

\begin{tabular}{|c|c|c|c|c|c|}
\hline SV & DF & SS & MS & $\mathbf{F}$ & Sig. \\
\hline & \multicolumn{5}{|c|}{ Drying Rate (g/hr) } \\
\hline Foaming Agent & 2 & 8.09 & 4.05 & 1.10 & 0.39 \\
\hline \multirow[t]{3}{*}{ Foam Stabilizer } & 2 & 14.25 & 7.12 & 2.68 & 0.15 \\
\hline & DF & SS & MS & $\mathbf{F}$ & Sig. \\
\hline & \multicolumn{5}{|c|}{ Protein Content (\%) } \\
\hline Foaming Agent & 2 & 0.020 & 0.01 & 26.31 & $0.001 *$ \\
\hline \multirow[t]{3}{*}{ Foam Stabilizer } & 2 & 0.002 & 0.001 & 0.26 & 0.78 \\
\hline & DF & SS & MS & $\mathbf{F}$ & Sig. \\
\hline & \multicolumn{5}{|c|}{ Vitamin C (\%) } \\
\hline Foaming Agent & 2 & 0.204 & 0.10 & 7.87 & $0.02 *$ \\
\hline Foam Stabilizer & 2 & 0.023 & 0.01 & 0.26 & 0.78 \\
\hline
\end{tabular}

Table 2

New Duncan multiple range test (NDMRT) of the effect of foaming agent on drying rate, vitamin $\mathrm{C}$ and protein content of foam-mat dried tomato pulp

\begin{tabular}{|l|l|l|l|}
\hline Foaming Agent (\%) & $\mathbf{5}$ & $\mathbf{1 0}$ & $\mathbf{1 5}$ \\
\hline Drying Rate (g/hr) & $19.21^{\mathrm{a}}$ & $21.53^{\mathrm{a}}$ & $20.46^{\mathrm{a}}$ \\
\hline Protein Content (\%) & $24.66^{\mathrm{a}}$ & $24.72^{\mathrm{b}}$ & $24.77^{\mathrm{c}}$ \\
\hline Vitamin C (\%) & $1.70^{\mathrm{a}}$ & $1.44^{\mathrm{b}}$ & $1.34^{\mathrm{b}}$ \\
\hline
\end{tabular}

Means with the same letter are not significantly different from each other at $P \leq 0.05$

Table 3

New Duncan multiple range test (NDMRT) of the effect of foam stabilizer on drying rate, vitamin $\mathrm{C}$ and protein content of foam-mat dried tomato pulp

\begin{tabular}{|l|l|l|l|}
\hline Foam Stabilizer (\%) & $\mathbf{0 . 2 0}$ & $\mathbf{0 . 4 0}$ & $\mathbf{0 . 8 0}$ \\
\hline Drying Rate (g/hr) & $18.74^{\mathrm{a}}$ & $20.68^{\mathrm{a}}$ & $21.78^{\mathrm{a}}$ \\
\hline Protein content (\%) & $24.71^{\mathrm{b}}$ & $24.71^{\mathrm{b}}$ & $24.74^{\mathrm{b}}$ \\
\hline Vitamin C (\%) & $1.43^{\mathrm{c}}$ & $1.56^{\mathrm{c}}$ & $1.49^{\mathrm{c}}$ \\
\hline
\end{tabular}

Means with the same letter are not significantly different from each other at $P \leq 0.05$ 
Table 4

Analysis of variance (ANOVA) showing the interactive effects of foam agent and foam stabilizer on the drying rate, protein and vitamin contents of foam-mat dried tomato pulp

\begin{tabular}{|l|l|l|l|l|l|l|}
\hline SV & & DF & SS & MS & F & Sig. \\
\hline $\begin{array}{l}\text { Foaming Agent (FA) X } \\
\text { Foam Stabilizer (FS) }\end{array}$ & $\begin{array}{l}\text { Drying Rate } \\
(\mathrm{g} / \mathrm{hr})\end{array}$ & 2 & 14.947 & 7.73 & 2.947 & 0.128 \\
\cline { 2 - 8 } & Protein (\%) & 2 & 0.022 & 0.11 & 85.123 & $0.000^{*}$ \\
\cline { 2 - 8 } & Vitamin C (\%) & 2 & 0.193 & 0.097 & 6.509 & $0.031^{*}$ \\
\hline
\end{tabular}

*Significant at $P \leq 0.05$

$S V$ - Sources of Variation; DF - Degree of Freedom; SS - Sum of Squares; MS - Mean

Squares; $F$-variance of group means per mean of within group variances; Sig. -

Significant, $P$ - estimated probabilities from experimental data.

\section{Effects of foam agent and foam stabilizer on the protein content of foam-mat dried tomato pulp}

The ANOVA in Table 1 has shown that the effect of foaming agent concentration is highly significant on the protein content of treated samples at $\mathrm{P} \leq 0.05$ significant level but foam stabilizer concentration had been found not to have any significant effect at this level. Table 2 has shown that foaming agent at various concentrations of 5\%,10\% and $15 \%$ had mean protein content of $24.66,24.72$ and $24.77 \%$ respectively, which shows that there is increase in the value of protein retention of the samples as the foaming agent concentration increases and Table 2 has further shown through NDMRT that the mean of the samples were significantly different from one another at $\mathrm{P} \leq 0.05$. Therefore it is important to vary foaming agent concentration and know the best one when the aim of the drying experiment is to have maximum retention of quality parameter such as the protein content. Table 3 has also shown the effect of foam stabilizer concentration on the protein content of the samples, which shows that at $0.20 \%, 0.40 \%$ and $0.80 \%$ CMC concentration, the mean protein content of the samples were $24.71,24.71,24.74 \%$ respectively and the NDRMT has shown that the means were not significantly different from one another at $\mathrm{P} \leq 0.05$. Table 4 reveals that the interaction between foaming agent and foam stabilizer had significant effects at $\mathrm{P} \leq 0.05$ on the protein content of the treated samples.

\section{Effects of foam agent and foam stabilizer on the vitamin $C$ content of foam-mat dried tomato pulp}

Analysis of variance in Table 1 has shown that the effect of foaming agent concentration is significant on the vitamin $C$ content of treated tomato at $P \leq 0.05$, but the effect of foam stabilizer concentration had no effect on the vitamin $\mathrm{C}$ concentration. These were further expressed in Table 2 and 3 using the NDRMT which in Table 2 show that foaming agent at $5 \%, 10 \%$ and $15 \%$ had mean values of vitamin $C$ to be $1.70,1.44$ and $1.34 \%$ respectively, hence it can be infer that increase in foaming agent concentration led to decrease in the value of vitamin $C$ retention this is similar to the findings of [19] on papaya pulp vitamin $\mathrm{C}$ content reduction with increased foam thickness also in agreement with the findings of [14] that beta carotene (an antioxidant like vitamin C) content of mango pulp decreases with increased foaming agent concentration. The mean of vitamin $\mathrm{C}$ at different foaming agent concentration were significantly different from one another at $\mathrm{P} \leq 0.05$. 
Therefore concentration of foaming agent is an important factor to be considered when putting vitamin $\mathrm{C}$ content retention in mind as a quality parameter. The effect of foam stabilizer is also shown in Table 2, which shows that CMC concentration at $0.2 \%, 0.4 \%$ and $0.8 \%$ had $1.43,1.56$ and $1.49 \%$ respectively as mean value of vitamin $\mathrm{C}$ content. Therefore the highest value of vitamin $\mathrm{C}$ was obtained at $0.4 \% \mathrm{CMC}$ concentration but NDMRT show that the means of vitamin $\mathrm{C}$ content of samples at different concentration were not significantly different from one another at $\mathrm{P} \leq 0.05$. Table 4 further express the interaction between foaming agent and foam stabilizer which is found not to be significant on the vitamin $\mathrm{C}$ content of the treated samples.

\title{
Conclusions
}

1. Drying rate of treated tomato pulp samples which were foam-mat dried is neither dependent on the foaming agent concentration level nor the foam stabilizer concentration level

2. Foaming agent concentration had significant effect on the protein content of treated tomato pulp samples, and increased foaming agent concentration resulted in increased protein content retention but foam stabilizer concentration had no significant effect at all on the protein content. Meanwhile the interaction between the two factors is considered to be highly significant on the value of protein derived.

3. Vitamin $\mathrm{C}$ content is an important quality parameter which is found that the foaming agent concentration had significant effect on its value, whereas foam stabilizer concentration had no significant effect on its value. But the interaction between the two factors is significant on the vitamin $\mathrm{C}$ level derived.

4. It is recommended that other factors should put into consideration for further research to ascertain which of them would have significant effect on drying rate of treated tomato pulp which will be subjected to foam-mat drying.

5. The foam stabilizer used (CMC) could be mixed with some other chemical solution at a certain proportion within safe limit for human consumption to be used for further research to determine how it would be able to influence the quality parameter, such as

6. Vitamin $\mathrm{C}$ and protein content of treated tomato pulp undergoing foam-mat drying process.

\begin{abstract}
Acknowledgements. The authors acknowledged Abdullah Abimbola Adegboyega, Department of Agricultural and Biosystems Engineering, University of Ilorin, Ilorin, Nigeria in data collection and for providing the equipment used to aid this research work. Also, the technologists in Food Chemistry Laboratory, University of Ilorin, Ilorin, Nigeria are acknowledged for helping to analyse the nutritional composition of the dried powder.
\end{abstract}

\section{References}

1. Romanik C. T. (2007), An urban - rural focus on food markets in Africa, the urban institute, Available at: http:/www.urban.org/sites/default/files/publication/31436/

411604-An-Urban-Rural-Focus-on-Food-Markets-in-Africa.pdf. 
2. Arah I. K., Ahorbo G. K., Anku E. K., Kumah E. K., Amaglo H. (2016), Postharvest handling practices and treatment methods for tomato handlers in developing countries, A Mini Review, Advances in Agriculture, Available at: http://dx.doi.org/10.1155/2016/6436945

3. (2011), World consumption, table tomato and processed tomato, tomato information services, Available at: http://www.tomatoland.com/documents/2248.pdf

4. Oladejo J. A. (2015), Effects of credit accessibility on performance of tomato market in Osun state, Nigeria, European Journal of Business and Management, 7(6), pp. 57-64.

5. Sahin F.H., Aktas T., Orak H., Ulger P. (2011), Influence of pretreatments and different drying methods on color parameters and lycopene content of dried tomato, Bulgarian Journal of Science, 17(6), pp. 867-881.

6. Canene-Adams K., Campbell J.K., Zaripheh S., Jeffery E.H., Erdman J.W. (2005), The tomato as a functional food, J. Nutr., 135, pp. 1226-1230.

7. Idah P.A., Obajemihi O.I. (2014), Effects of osmotic pre-drying treatments, duration and drying temperature on some nutritional values of tomato fruit, Academic Research International, 5(2), pp. 119-126.

8. Thuwapanichayanan R., Prachayawarakorn S., Soponronnarit S. (2012), Effects of foaming agents and foam density on drying characteristics and textural property of banana foams, LWT - Food Science and Technology, Zürich, 47, pp. 348-357.

9. Lewicki P.P. (2006), Design of hot air drying for better foods, Trends in Food Science and Techonology, 17(4), pp. 153-163.

10. Sahin F.H., Aktas T., Orak H., Ulger P. (2011), Influence of pretreatments and different drying methods on color parameters and lycopene content of dried tomato, Bulgarian Journal of Science, 17(6), pp. 867-881.

11. Bag S.K., Srivastav P.P., Mishra H.N. (2011), Optimization of process parameters for foaming of bael (Aegle marmelos L. ) fruit pulp. Food and Bioprocess Technology, 4(8), pp. 1450-1458.

12. Thuwapanichayanan R., Prachayawarakorn S., Kunwisawa J., Soponronnarit S. (2011), Determination of effective moisture diffusivity and assessment of quality attributes of banana slices during drying. LWT-Food Science and Technology, Zürich, 44, pp. 1502 1510

13. Sharada S. (2013), Studies on effect of various operating parameters and foaming agent drying of fruits and vegetables, International Journal of Modern Engineering Research, 3(3), pp. 1512-1519.

14. Wilson R.A., Kadam D.M., Chadha S., Sharma M. (2012), Foam mat drying characteristics of mango pulp, International Journal of Food Science and Nutrition Engineering, 2(4), pp. 63-69.

15. Idah P.A., Obajemihi O.I., Adeboye O.A., Olaniyan, A.M. (2014), Assessment of osmotic pre-drying treatment on drying rates of fresh tomato Fruits, Nigerian Journal of Technological Development, 11(1), pp. 22-26.

16. (2000), AOAC Official Methods of Analysis, 15th edn., Association of Official Analytical Chemists, Arlington, Virginia, USA.

17. Fernandes R.V.B., Queiroz F., Botrel D.A., Rocha V.V., Lima C.F., Souza V.R. (2012), Foam mat drying of tomato pulp, Bioscience Journal Uberlandia, 29(4), pp. 816-825.

18. Kudra T., Ratti C. (2006), Foam-mat drying, energy and cost analyses, Canadian Biosystems Engineering, 48, pp. 3.27-3.32.

19. Kandasamy P., Varadharaju N., Kalemullah S. (2012), Foam-mat drying of papaya (carica papaya l) using glycerol monostrate as foaming agent, Food Science and Management, 9, pp. 17-27. 